\title{
ARAH POLITIK ISLAM MALAYSIA: KEMENANGAN PAKATAN HARAPAN DALAM PEMILU
}

\author{
Ismail Suardi Wekke ${ }^{12}$ \\ ${ }^{1}$ Sekolah Tinggi Agama Islam Negeri (Sorong), Indonesia \\ ${ }^{2}$ Universitas Muhammadiyah Sorong, Indonesia \\ Email: ismail@ stain-sorong.ac.id
}

\begin{abstract}
ABSTRAK
Politik Malaysia memberikan kejutan. Kemenangan Pakatan Harapan dengan kursi mayoritas. Tidak saja di Parlemen Malaysia tetapi juga menambah negeri yang sebelumnya hanya dua dengan lima negeri baru. Begitu pula dengan Partai Islam Se-Malaysia dengan tambahan satu negeri lagi yang pernah direbutnya 1999, Terengganu. Pergantian kepemimpinan ini menjadi sebuah tanda aras akan arah politik Malaysia. Walau dengan pemain lama tetapi dengan kendaraan baru.
\end{abstract}

Kata Kunci: Politik, Islam, Malaysia

\section{Pendahuluan}

Walau lembaga riset Envoke, sudah merilis prediksi kemenangan Pakatan Harapan ( $\mathrm{PH})$ sehari sebelum pemungutan suara pemilihan umum Malaysia Ke-14, menyimak kemenangan koalisi pimpinan Tun Mahathir, tetap saja sebuah kejutan. Dengan usia yang menjejak 92 tahun, masih mampu begadang sampai pukul 4 dinihari untuk menanti pengumuman hasil pemilihan umum. Ini sebuah energi tersendiri, dimana Tun Mahathir masih mampu menggerakkan koalisi PH untuk bersama-sama menggapai Putra Jaya.

Bukan itu saja, kemenangan Pakatan Harapan dilalui dengan banyak proses dan juga riak-riak yang menyumbang bagi kejatuhan Barisan Nasional (BN) setelah berkuasa selama 60 tahun. Ketika berada di Malaysia, 2006-2009, sudah ada kekhawatiran dari pihak Barisan Nasional ketika. Bahwa dengan belajar pada jatuhnya Partai Golkar di Indonesia, tidak ada jaminan bahwa Barisan Nasional juga akan berkuasa selamanya.

Sebelum ini, para pengamat dari perguruan tinggi dalam negeri Malaysi, maupun pengamat politik dari perguruan tinggi luar negeri, masih saja memperediksi kemenangan Barisan Nasional dengan anggapan bahwa stabilitas ekonomi masih terkawal. Sehingga para pemilih tidak akan menjatuhkan pilihan pada pihak oposisi. Namun, itu hanya satu faktor dalam amatan para pakar. Ada pertimbangan dan aspek lain, sehingga akhirnya Malaysia akan dipimpin perdana mentri baru. 


\section{Tumbangnya Petahana}

Kekhawatiran kurang lebih sepuluh tahun yang lalu itu, terbukti hari ini (10/5). Barisan Nasional tumbang dan merekalah yang akhirnya menjadi pembangkang (oposisi). Negeri-negeri yang sebelumnya mereka kuasai, jatuh satu persatu. Walau Terengganu berpindah ke Partai Islam Se-Malaysia (PAS), tetap saja bukan di tangan Barisan Nasional lagi. Secara historis, Terengganu sebelumnya pernah dikuasai juga PAS selama satu periode. Sementara Kelantan tetap saja di tangan PAS.

Johor, Perak, Kedah, Melaka, dan Negeri Sembilan, semuanya beralih ke Pakatan Harapan. Adapun Selangor tetap di tangan Partai Keadilan Rakyat (PKR) yang sudah memasuki periode ketiga. Demikian pula Pulau Pinang yang juga sudah periode ketiga di tangan Democratic Action Party (DAP). Barisan Nasional masih memegang dua negeri yaitu Pahang dan Perlis. Sementara Sabah jikalau saja partai-partai di luar Barisan Nasional bersatu, juga akan hilang dari genggaman $\mathrm{BN}$.

Dua hal yang menjadi jalan bagi kemenangan Pakatan Harapan. Pertama, sejak awal tokoh-tokoh kunci meninggalkan Tun Najib Tun Razak dengan pelbagai alasan. Beberapa diantaranya dipecat karena memiliki pandangan berbeda. Seperti Muhyiddin Yasin didepak dari posisi Timbalan Perdana Menteri yang akhirnya mendirikan partai bersama Tun Mahathir. Begitu juga, Shafie Afdhal yang membentuk Partai Warisan di Sabah. Terakhir, menjelang pemungutan suara Tun Daim dan Tun Rafidah, dikeluarkan dari UMNO karena dianggap mendukung Tun Mahathir.

Kesemuanya itu kemudian melemahkan kekuatan UMNO yang menjadi pilar utama Barisan Nasional. Sementara pemilihan umum ke-13 sebelumnya sudah membuktikan bahwa dukungan Barisan Nasional dari pihak China dan India tidak lagi memadai.

Kedua, ada pemaafan dan rekonsiliasi. Datuk Seri Anwar Ibrahim terdepak dari kursi Timbalan Perdana Mentri yang saat itu justru diprediksi menjadi Perdana Mentri dengan alasan korupsi. Bahkan, dijebloskan ke penjara diawali tuduhan sodomi. Namun, justru partai yang diririkan Datuk Seri Anwar Ibrahim-lah yang kemudian menjadi bagian untuk mengantar Tun Mahathir kembali ke panggung politik.

Datuk Seri Anwar Ibrahim dari balik jeruji memberikan pernyataan untuk melupakan masa lalu. Setelahnya, istri Datuk Seri Anwar Ibrahim yang terjun ke politik sejak suaminya dilengserkan dari jabatan Timbalan Perdana Mentri bahu membahu dengan Tun Mahathir untuk 
mendulang suara dalam pemilihan umum. Seluruh perangkat Partai Keadilan Rakyat tidak lagi mengungkap masa lalu itu. Padahal, mereka berjuang tidak saja di parlemen, juga di jalanan ketika perdana mentri kala itu masih Tun Mahathir.

Dalam konteks yang berbeda namun juga bisa dipotret menggunakan aspek ini, kemenangan Anies Baswedan, dan juga Nelson Mandella di Afrika Selatan, keduanya memenangkan pertarungan politik karena kesediaan untuk memaafkan tindakan-tindakan masa lalu. Ketika Anies Baswedan menjadi bagian tim kampanye Joko Widodo, tentu dalam beberapa kasus melukai perasaan calon presiden Prabowo Subianto. Hanya saja, baik Prabowo maupun Anies bersedia melupakan itu dan bekerja sama untuk menggapai kursi gubernur DKI. Demikian pula, Nelson Mandella yang pernah dipenjara oleh rezim di Afrika Selatan. Berdamai dan menerima keadaan itu, dan kemudian ini bisa melapangkan jalan menuju kursi presiden.

\section{Konstruksi Teoritis}

Malaysia dengan konsepsi keislaman (Wekke, 2013) tetap menjadi ketuanan Melayu. Semasa kepemimpinan awal YAB Mahathir Mohamad menjadi perkenalan posisi pribumi. Keberadaan orang Bugis di Malaysia (Bustami \& Wekke, 2016; Wekke, 2017) juga akan menjadi sebuah pertanyaan. Sebuah kasus dimana YAB Mahathir Mohamad menyebut Bugis secara khusus. Sementara itu, dengan tiga etnis yang dalam bahasa Melayu disebut bangsa, juga akan menemukan tantangan harmoni (Wekke, 2016). Begitu pula dengan isu Myanmar, pemerintahan baru Malaysia akan ditunggu sikapnya (Wekke, Hasbi, Mawardin, Ladiqi, \& Salleh, 2018).

\section{Penutup}

Dalam politik praktis, ketersinggungan tidak bisa diabadikan. Ini akan menghambat jalan-jalan menuju kemenangan. Sebuah lagu dangdut dengan satu penggalan "masa lalu biarlah masa lalu”. Ini sejalan juga dengan tindakan-tindakan politik praktis. Jangan sampai hanya halhal kecil kemudian menjadi jalan bagi hilangnya kekuasaan.

Terakhir, usia bukanlah soal penting dalam politik praktis. Dengan umur hampir mencapai 100 tahun, Tun Mahathir masih saja mampu meraih kursi perdana mentri. Apatah lagi Datuk Seri Anwar Ibrahim. Jabat tangan, sudah dilakukan. Begitu pula campur tangan sudah 
digerakkan. Saat ini, menunggu garis tangan saja. Untuk menyaksikan apakah Datuk Seri Anwar Ibrahim memiliki taqdir untuk menjadi perdana mentri?.

\section{DAFTAR PUSTAKA}

Bustami, R., \& Wekke, I. S. (2016). Migrants In Nusantara: Indonesian and Malaysian Perspectives. Journal of Nusantara Studies (JONUS), 1(2), 63-74.

Wekke, I. S. (2013). Politik, Agama Dan Negara: Pemerintahan Islam Di Malaysia. Millah: Jurnal Studi Agama, 12(2), 291-328.

Wekke, I. S. (2016). Harmoni Sosial Dalam Keberagaman Dan Keberagamaan Masyarakat Minoritas Muslim Papua Barat. KALAM, 10(2), 295-312.

Wekke, I. S. (2017). Migrasi Bugis dan Madura di Selatan Papua Barat: Perjumpaan Etnis dan Agama di Minoritas Muslim. INTELEKTUALITA, 6(2), 163-180.

Wekke, I. S., Hasbi, H., Mawardin, M., Ladiqi, S., \& Salleh, M. A. (2018). Muslim Minority in Myanmar: A Case Study of Myanmar Government and Rohingya Muslims. Walisongo: Jurnal Penelitian Sosial Keagamaan, 25(2). 